\title{
EFFECTIVE PRESENTATION SKILL PADA KEGIATAN APERSEPSI MATERI PENDIDIKAN AGAMA ISLAM
}

\author{
Desy Aniqotsunainy
}

Sekolah Tinggi Agama Islam Masjid Syuhada Yogyakarta

E-mail: desyaniqo@yahoo.com

\begin{abstract}
Abstrak
Kreativitas merupakan proses mental yang melibatkan pemunculan gagasan atau konsep baru atau hubungan baru antara gagasan dengan konsep yang sudah ada. Konsep pengembangan kreativitas guru dapat dilakukan cara membuat inovasi, memberikan motivasi dan mampu membangun makna dalam penyampaian materi. Cara penyampaian dan penyajian materi Pendidikan Agama Islam dengan menghubungkan keterkaitan yang mengarah pada makna adalah jantung dari pembelajaran kontekstual. Karena itu kekuatan presentasi salah satunya terletak pada pembukaan yang baik dan menarik presentasi yang meyakinkan.
\end{abstract}

Kata kunci : Keterampilan, Presentasi, Kreativitas, Materi, Pendidikan Agama Islam

\section{Abstract}

Creativity is a mental process involving the emergence of new ideas or concepts or new relationships between ideas and existing concepts. The concept of teacher creativity development can be done how to make innovation, provide motivation and able to build meaning in the delivery of material. The way of delivering and presenting Islamic Studies by linking the linkage that leads to meaning is the heart of contextual learning. Therefore the strength of the presentation of one of them lies in a good opening and interesting convincing presentation.

Keywords : Skills, Presentation, Creativity, Content, Islamic Studies 
Desy Aniqotsunainy : Effective Presentation Skill pada Kegiatan Apersepsi Materi Pendidikan Agama Islam

\section{A. PENDAhuluan}

Sebuah pertanyaan asal mula kreativitas itu berasal dari bakat seseorang atau harus dirangsang dengan latihan. Karena tidak semua orang yang memiliki potensi bakat untuk kreatif. Begitu pula guru, tidak semuanya yang memiliki kreativitas. Masih ada guru yang mengandalkan kondisi lingkungan pembelajaran apa adanya. Sudah merasa cukup dengan apa yang sudah dijalankan dan dicapai dalam mengajar. Padahal perkembangan zaman, seorang guru harus mampu beradaptasi dan berfikir cepat dalam menghadapi tugas keguruannya.

Secara sederhana kreativitas diri sering diartikan sebagai suatu sikap mental terhadap ide-ide baru, atau suatu konsep baru diantara ide-ide yang sudah ada. Permasalahannya adalah tentang cara membangun kreativitas diri, beragam metode untuk mengembangkan dan mengasah potensi kreativitas, namun pada jurnal ini memfokuskan pada kreativitas guru dalam penyampaian materi yang akan disampaikan. Prinsip yang dulu pernah diajarkan dalam amaliyah tadris (praktek mengajar), yaitu: At-thariqah ahammu min al-Maaddah. Sebagus apapun materi yang guru sampaikan, jika cara penyampaiannya kurang bagus dan tidak sesuai dengan target yang dituju, maka sulit bagi mereka untuk mencernanya. Beda jika cara penyampaiannya bagus dan mengena. Dengan demikian, benar bahwa metode merupakan salah satu aspek utama yang harus diperhatikan. Di sinilah pentingnya siapapun yang ingin mengajar, untuk mempelajari berbagai metode pengajaran. Bukan sekedar menyampaikan begitu saja, lalu marah-marah dan menyalahkan lawan bicara kala tidak bisa memahami makna 
Desy Aniqotsunainy : Effective Presentation Skill pada Kegiatan Apersepsi Materi Pendidikan Agama Islam

dari materi yang akan disampaikan. Sebagaimana Allah berfirman dalam Al-Qur'an selalu diperintahkan: 206

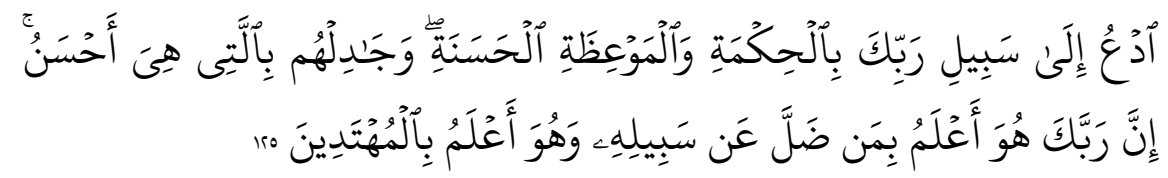

Artinya:

"Serulah (manusia) kepada jalan Tuhan-mu dengan hikmah dan pelajaran yang baik dan bantahlah mereka dengan cara yang baik. Sesungguhnya Tuhanmu Dialah yang lebih mengetahui tentang siapa yang tersesat dari jalan-Nya dan Dialah yang lebih mengetahui orang-orang yang mendapat petunjuk." (QS.An-Nahl: 125)

Cara penyampaian (presentation skill) tidak terpisahkan dari kriteria profesionalisme guru. Bahkan merupakan salah satu dari berbagai keterampilan yang harus dimiliki guru. Keberhasilan guru dalam menyampaikan materi adalah cara penyajiannya menarik, kreatif dan materinya dapat dipahami siswa. Melalui tulisan ini penulis mengembangkan kajian tentang model presentation skiil pada materi pendidikan agama Islam yang efektif dan menarik.

\section{B. PEMBAHASAN}

\section{Pengembangan Guru Kreatif}

Ada beragam julukan yang diberikan kepada sosok guru. Salah satu yang paling terkenal adalah "Pahlawan Tanpa Tanda Jasa". Julukan ini mengindikasikan betapa besarnya peran dan jasa yang dilakukan guru sehingga guru disebut sebagai pahlawan. Guru adalah sosok penting yang cukup menentukan dalam proses pembelajaran. Walaupun sekarang ini ada berbagai sumber belajar alternatif yang lebih

206 Departemen Agama RI, Al-Qur'an dan Terjemahnya, (Surabaya: Surya Cipta Aksara,1995), hlm.421 
Desy Aniqotsunainy : Effective Presentation Skill pada Kegiatan Apersepsi Materi Pendidikan Agama Islam

kaya, seperti buku, jurnal, majalah, internet, maupun sumber belajar lainnya, tetapi guru tetap menjadi kunci untuk optimalisasi sumber-sumber belajar yang ada. Guru tetap menjadi sumber belajar yang utama. Tanpa guru, proses pembelajaran tidak akan dapat berjalan secara maksimal.

Seorang guru sangat berpengaruh terhadap hasil belajar yang dapat ditunjukkan oleh peserta didiknya. Untuk itu, apabila seseorang ingin menjadi guru yang profesional maka sudah seharusnya ia dapat selalu meningkatkan wawasan pengetahuan akademis dan praktis melalui jalur pendidikan berjenjang ataupun up grading dan atau pelatihan yang bersifat in service training dengan rekan-rekan sejawatnya. Perubahan dalam cara mengajar guru dapat dilatihkan melalui peningkatan kemampuan mengajar sehingga kebiasaan lama yang kurang efektif dapat segera terdeteksi dan perlahan-perlahan dihilangkan. Untuk itu, maka perlu adanya perubahan kebiasaan dalam cara mengajar guru yang diharapkan akan berpengaruh pada cara belajar siswa.

Perubahan paradigma pembelajaran tidak mengurangi kedudukan penting peranan guru. Penting sekali guru menyadari perannya yang berubah, guru berperan sebagai pengarah, pembimbing, pemberi kemudahan dengan menyediakan berbagai fasilitas belajar, pemberi bantuan bagi peserta yang mendapat kesulitan belajar, dan pencipta kondisi yang merangsang dan menantang peserta didik untuk berpikir dan bekerja (melakukan).

Mengubah dari sekedar metode ceramah dengan berbagai variasi metode yang lebih relevan dengan tujuan pembelajaran, memperkecil kebiasaan cara belajar peserta 
Desy Aniqotsunainy : Effective Presentation Skill pada Kegiatan Apersepsi Materi Pendidikan Agama Islam

yang baru merasa belajar dan puas kalau banyak mendengarkan dan menerima informasi (diceramahi) guru, atau baru belajar kalau ada guru. 207 Dengan memahami problematika pembelajaran, dapat ditarik beberapa konsep pengembangan guru kreatif diantaranya sebagai berikut:

a. Guru selalu membuat inovasi

Setiap kali mengadakan pertemuan dengan peserta didik, guru harus mampu menghadirkan hal-hal yang baru untuk diketahui oleh peserta didik. Inovasi pembelajaran terlihat dari cara guru membangun komunikasi antara guru dan peserta didik. Komunikasi yang efektif sangat tergantung pada kecakapan seseorang dalam membangun komunikasi saat pembelajaran.

b. Guru berperan sebagai motivator

Guru ditinjau dari standar proses adalah motivator, Peraturan Pemerintah No.19/2005 pasal 19 berbunyi sebagai berikut:" Satuan pendidikan diselenggarakan secara interaktif, inspiratif, menyenangkan, menantang memotivasi peserta didik untuk berpartisipasi aktif serta memberikan ruang yang cukup bagi prakarsa, kreativitas, dan kemandirian sesuai dengan bakat, minat dan perkembangan fisik dan psikologis peserta didik. Satusatnnya peran guru dalam proses ini adalah motivator. Motivasi datang dari kejutan kala menemukan gagasangagasan yang sebelumnya tak terpikirkan. Motivasi juga datang dari membandingkan diri dengan orang lain dan dari berkompetisi dengan orang lain, motivasi juga datang dari kemahiran. Sehingga melakukan kegiatan berfikir

207 Naim, Ngainun. 2009. Menjadi Guru Inspiratif. Yogyakarta: Pustaka Pelajar 
Desy Aniqotsunainy : Effective Presentation Skill pada Kegiatan Apersepsi Materi Pendidikan Agama Islam

dengan yakin dan efektif merupakan sumber motivasi yang tinggi

c. Membangun hubungan untuk menemukan makna

Keterkaitan yang mengarah pada makna adalah jantung dari pembelajaran kontekstual. Apalagi materi pendidikan Agama Islam berikut diantaranya:

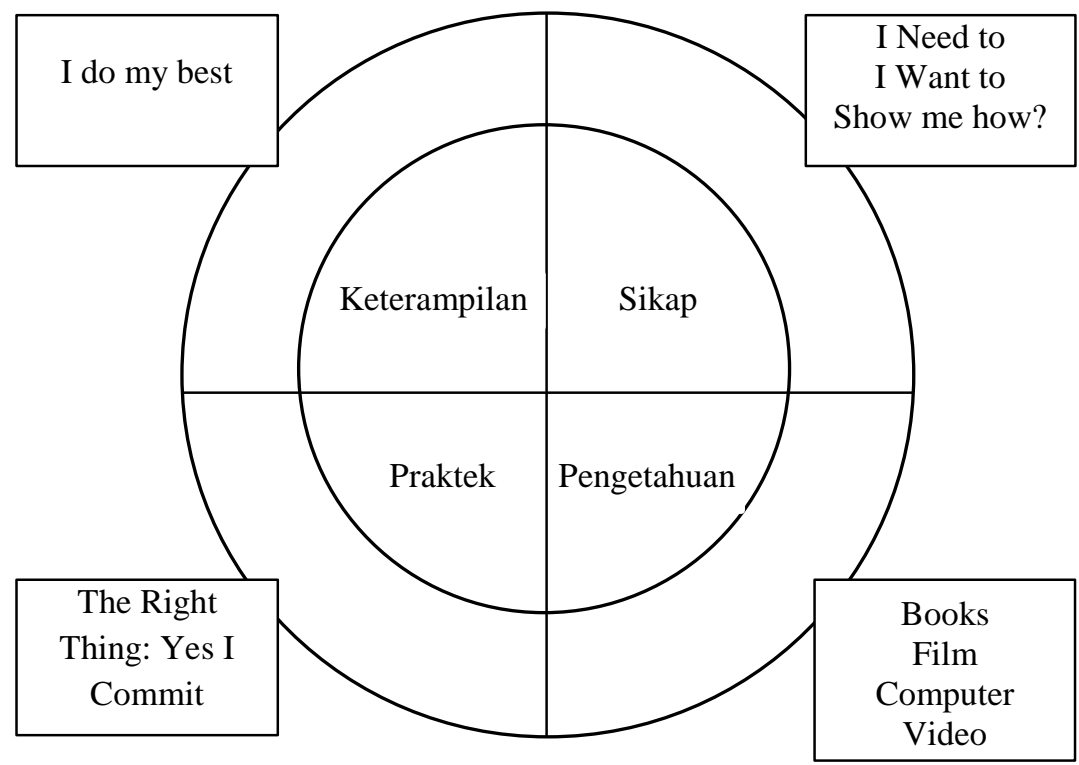

Hasan Abdullah Sahal mengatakan "at-thariqah ahammu mina-l-maddah, wa al-mudarris ahammu mina-tthariqah, wa ruhu-l-mudarris ahammu mina-l-mudarris nafsihi. Metode lebih penting dari materi. Materi apapun yang disampaikan, jika menggunakan metode yang benar, maka akan dapat diterima para siswa dengan baik. Sebaliknya, materi yang telah dipersiapkan dengan matang, akan menjadi hampa, tanpa metode yang baik. Setelah merenung dan melalui pemikiran yang mendalam, ditambah lagi ada suatu kejadian yang tak dapat 
Desy Aniqotsunainy : Effective Presentation Skill pada Kegiatan Apersepsi Materi Pendidikan Agama Islam

disampaikan dalam tulisan ini, beliau menganggap bahwa metode memang berpengaruh, namun tidak mutlak. Yang berpengaruh adalah the man, manusianya, orangnya, almudarris nafsuhu ('guru itu sendiri'). Tak berhenti pada kata guru, ada sesuatu yang lebih penting dari itu, yakni jiwa seorang guru, the soul, atau ruh al-mudarris.

\section{Presentation Skill}

a. Konsep Presentasi

Pengertian presentasi dalam Kamus Besar Bahasa Indonesia adalah penyajian kepada orang-orang yang diundang. Presentasi merupakan bentuk menyampaikan ide atau pesan kepada audiens. Teknik presentasi adalah bagian dari ilmu komunikasi. Komunikasi disini bermakna penyampaian pesan dari pengirim kepada penerima, melalui suatu media. Skill berarti keterampilan/teknik, presentation skill disini dimaknai penguasaan keterampilan komunikasi dalam presentasi dengan baik dan benar.

Dengan belajar teknik presentasi, maka seseorang akan dapat berkomunikasi atau menyampaikan pesan kepada audiens dengan lebih efektif. Seorang presenter (orang yang menyampaikan presentasi) perlu mengetahui persiapan sebelum memulai presentasi. Berikut persiapan yang dipahami:

1) Mempersiapkan APA yang akan disampaikan

Luangkan waktu untuk mempelajari "Apa yang akan disampaikan" Jangan bicara apa yang tidak perlu, Jangan bicara apa yang anda tidak sukai, Baca referensi/buku-buku/Al-Qur'an dan Hadis tentang "apa yang akan disampaikan", serta materi konstekstual 
Desy Aniqotsunainy : Effective Presentation Skill pada Kegiatan Apersepsi Materi Pendidikan Agama Islam

2) Mengidentifikasi SIAPA pendengar/audiens

Pengenalan audiens adalah proses untuk mendapatkan informasi dan mengembangkan pemahaman terhadap pendengar yang akan dihadapi, supaya guru dapat merencanakan, membawakan dan mempersiapkan berbagai informasi yang efektif.

3) Mengidentifikasi ciri-ciri pendengar, gunakan teknik/strategi

Dalam mengidentifikasi ciri-ciri pendengar, maka perlu dilakukan analisis pada tingkat pemahaman, latar belakang usia, pendidikan, jenis kelamin, kondisi lingkungan, kebutuhan pendengar, dan tujuan khusus serta ekspektasi ke depan dari materi yang disampaikan. Maka pembelajaran aktif merupakan salah satu cara yang bisa dilakukan guru untuk mencapai tujuan pembelajaran.

4) Mengatur waktu presentasi dengan membuat lesson plan/struktur penyampaian. Menentukan KAPAN dan berapa lama introducing, penyampaian isi, game, diskusi kelompok, ice breaking dan lainnya.

5) Teknik penyampaian

Mulai dengan hal yang sederhana/ netral, Kata/kata atau kalimat efektif, Gunakan contoh : data/statistic, ilustrasi, gambar, film, cerita, Gunakan bahasa tubuh yang benar guna menopang ucapan anda, Motivasi audiens untuk mendengar, Konfirmasikan pikiran dan gagasan apakah sudah diterima

b. Persiapan presentasi

Kemudian langkah-langkah dalam mempersiapkan presentasi yang efektif yaitu: 
Desy Aniqotsunainy : Effective Presentation Skill pada Kegiatan Apersepsi Materi Pendidikan Agama Islam

1) Mempersiapkan bahan

Dalam tahap persiapan bahan ada beberapa yang harus dilakukan yaitu menentukan topik, tentukan pesan utama /garis besar, siapkan ilustrasi untuk mendukung pesan utama, siapkan kesimpulan, siapkan lesson plan/struktur penyampaian, tentukan waktu yang dibutuhkan, latihan kepada teman (Dry-run).

2) Menentukan Topik

Beberapa pertanyaan tentag apa yang harus anda sampaikan? Apa topik yang dibutuhkan audiens? Mengapa saya menyampaikan topik ini?. inilah beberapa pertanyaan yang harus dijawab diri anda sebelum menentukan topik presentasi. Dalam dunia pendidikan komponen materi sudah ada di Silabus, sehingga guru mengembangkan materi tersebut dalam topik-topik yang tepat dan sesuai dengan kebutuhan siswa. Usahakan topik guru menarik dan menggugah siswa untuk mendengarkan.

3) Isi lesson plan

Lesson Plan (rencana pelajaran) dapat bertindak sebagai panduan untuk membantu guru dalam mempersiapkan satu sesi pertemuan. Isi lesson plan memuat judul, sasaran, ringkasan kegiatan/isi, waktu, metode, media, peralatan.

\section{Effective Presentation Skill Pada Kegiatan Apersepsi materi pendidikan agama Islam}

Orang cenderung mengingat lebih baik apa-apa yang paling awal mereka lihat dan dengarkan. Dalam dunia Psikologi dikenal dengan istilah efek awalan (Primacy Effect). Pembukaan yang baik akan menarik perhatian audiens. Apa 
Desy Aniqotsunainy : Effective Presentation Skill pada Kegiatan Apersepsi Materi Pendidikan Agama Islam

yang guru sampaikan di awal ketika membuka presentasi akan menjadi informasi yang paling diingat. Karena itu kekuatan presentasi salah satunya terletak pada pembukaan yang baik dan menarik serta penutupan presentasi yang meyakinkan.

Penting untuk memahami tentang gaya belajar, pengertian gaya belajar adalah cara yang cenderung dipilih seseorang untuk menerima informasi dari lingkungan dan memproses informasi tersebut. 208 Bobbi DePorter dalam Quantum Learning mendefinisikan bahwa modalitas belajar adalah cara termudah bagi individu dalam menyerap informasi. 209 Gaya belajar menurut Nasution adalah cara ia (siswa) bereaksi dan menggunakan perangsang-perangsang yang diterimanya dalam proses belajar. ${ }^{210}$ Pembahasan ini difokuskan pada cara guru menyajikan materi sesuai dengan konsep pembelajaran, di awali dari kegiatan apersepsi, membuka pelajaran dengan mengacu pada menarik perhatian siswa, menimbulkan motivasi, memberi acuan dan membuat kaitan materi. Komponen awal kegiatan pembelajaran ini harus didasari pemahaman tentang fungsi pembukaan dalam sebuah presentasi, seorang guru perlu memahami fungsi pembukaan dalam presentasi yaitu:

a. Agar siswa memahami tujuan presentasi Anda

Guru diwajibkan membuat rumusan tujuan, tujuan menggambarkan arahan untuk selalu berada "on the right track", sebagaimana anjuran Nabi Muhammad adalah: “ Mulailah dengan do'a”. Do'a adalah sebuah harapan, dan

208 Joko Susilo, Gaya Belajar Menjadikan Makin Pintar, (Yogyakarta: Press, 2006), hlm. 94

209 Bobbi DePorter,dkk, Quantum Learning...hlm. 111

210 Nasution, Berbagai Pendekatan Dalam Proses Belajar dan Mengajar, (Jakarta, Bumi Aksara, 2006), hlm. 93 
Desy Aniqotsunainy : Effective Presentation Skill pada Kegiatan Apersepsi Materi Pendidikan Agama Islam

harapan umumnya muncul dalam bentuk visual yang diproses di belahan otak kanan. Artinya, mulailah suatu perbuatan dengan tujuan. 211

b. Mendapat Gambaran Umum atas Apa yang Disampaikan

Pembukaan presentasi mirip dengan opening sebuah film. Ketika Anda menonton film, 5 menit pertama sangat krusial karena akan menentukan apakah Anda akan menonton film tersebut sampai selesai atau segera meninggalkannya. Seperti sebuah film, pembukaan presentasi berfungsi untuk memberikan gambaran umum kepada audiens apa yang akan mereka dengarkan dalam beberapa waktu ke depan.

c. Menciptakan motivasi dan rasa ingin tahu siswa, kesempatan guru untuk menciptakan motivasi yang sama bagi audiens agar mereka merasa perlu mendengarkan presentasi Anda sampai selesai.

Pembukaan yang baik juga akan menciptakan rasa ingin tahu peserta didik sehingga mereka akan terus mendengarkan guru. Berikut langkah-langkahnya:

1) Membuka Presentasi Dengan Menyampaikan Maksud dan Tujuan

Membuka presentasi dengan menyampaikan maksud dan tujuan. Dengan cara ini, audiens akan mengerti apa yang akan mereka dapatkan dari presentasi Anda. Anda juga bisa menetapkan harapan (ekspektasi) audiens tentang berapa lama presentasi akan berlangsung dan apa saja yang akan dibahas. Sampaikan apa yang akan Anda bahas, berapa lama

211 Ary Ginanjar Agustian, Emotional Spiritual Quotient, Jakarta: Arga Wijaya Persada, 2001), hlm.220 
Desy Aniqotsunainy : Effective Presentation Skill pada Kegiatan Apersepsi Materi Pendidikan Agama Islam

waktu yang dibutuhkan, dan apa manfaat yang bisa diambil audiens setelah presentasi selesai.

Contoh :

"Murid-muridku yang tersayang. Assalamu'alaikum $W r . W b$. selamat pagi. Saya sangat senang hari ini niat tulus belajar agama, supaya diridhoi Alloh Dalam waktu Enam puluh menit ke depan, saya akan menjelaskan materi sedekah yang akan memberikan manfaat untuk siswa dalam memahami keutamaan sedekah menurut Al-Qur'an dan Sunnah. Di akhir presentasi nanti, siswa akan bisa memahami manfaat yang akan didapatkan dari materi ini, serta melaksanakan sedekah. Dengan demikian, siswa dapat memahami keajaiban sedekah membuat rezeki penuh barokah bagi diri sendiri dan keluarga".

2) Membuka Presentasi Dengan Sebuah Pertanyaan

Apa yang akan Anda lakukan ketika seseorang mengajukan sebuah pertanyaan? Anda mengajukan pertanyaan ketika membuka sebuah presentasi. Audiens akan berusaha berpikir dan mencari jawabannya meskipun mereka tidak menjawab langsung pertanyaan Anda.

Contoh :

"Saya ingin mengajukan pertanyaan kepada Anda. Dalam 1 tahun ada 12 bulan, 52 minggu, 365 hari, 8.760 jam, 525.600 menit dan 31.536.000 detik. Ada berapa jamkah total anda berbuat baik selama kurun waktu tersebut?" 
Desy Aniqotsunainy : Effective Presentation Skill pada Kegiatan Apersepsi Materi Pendidikan Agama Islam

3) Membuka presentasi dengan cerita

Mengapa cerita? Cerita mudah diingat. Sebuah cerita yang relevan mampu menggugah emosi audiens. Mengajak mereka merenung dan menghayati cerita sebelum mendengarkan presentasi Anda.

Contoh:

"Ada seorang bersedekah Rp. 1.000 di satu shalat jum'at, setelah shalat Jum'at dia makan di warung dekat masjid. Ketika akan bayar, makanannya dibayarin orang. Jumlahnya katakanlah mendekati Rp. 10.000. tapi orang ini tidak menyadari dengan ilmunya bahwa peristiwa ini ada kaitannya dengan sedekahnya yang Rp. 1.000 di waktu shalat Jum'at. Orang ini tetap bersyukur kepada Allah, ada yang membayar makanannya. Tapi orang ini bersyukur biasa, bersyukur bukan bersyukur karena ilmunya. 212

Penggalian kisah-kisah baik tekstual atau kontekstual tersebut menyuguhkan kepada audiens ternyata di balik kisah itu ada sebuah metode yang akan berulang kejadiannya, bahkan bisa menjadi amaliah yang memiliki derajat tinggi di hadapan Allah SWT.

4) Membuka Presentasi Dengan Data atau Fakta.

Jika presentasi Anda memiliki data dan fakta yang menarik, Anda bisa menggunakan informasi tersebut untuk membuka presentasi. Data bisa mengajak orang untuk berpikir. Tidak hanya itu, data

212 Yusuf Mansur, The Miracle of Giving: Keajaiban Sedekah, (Jakarta: Zikrul Hakim, 2008), hlm. 6 
Desy Aniqotsunainy : Effective Presentation Skill pada Kegiatan Apersepsi Materi Pendidikan Agama Islam dan fakta mampu menciptakan efek dramatis tanpa harus didramatisir.

Contoh:

"Rata-rata umur manusia saat ini meninggal dunia antara $60 \mathrm{~s} / \mathrm{d} 70$ tahun, Jikapun ada yang lebih dari itu masih hidup, maka merupakan suatu bonus umur dari Allah. Sekarang kita samakan saja rata-rata manusia meninggal plus minus di usia 65 tahun. Masa mulai baligh, yaitu awal dari seorang anak manusia mulai di perhitungkan amal baik atau buruknya selama hidup, umumnya bagi laki-laki adalah 15 tahun dan wanita 12 tahun. Sekarang, mari mencari waktu yang tersisa untuk beribadah pada Allah. Contoh gunakan saja rumus sederhana : Umur rata-rata kematian - Awal Baligh. Jika rata-rata umur seseorang meninggal pada usia 65 tahun dikurang 15 tahun saat awal ia baligh maka waktu yang tersisa adalah 50 tahun. Apa dan bagaimana perilaku kita selama 50 tahun masa hidup itu? Jika dikalikan lagi angka 50 tahun dengan 365 hari/tahunnya maka diperoleh angka 18.250 hari. Nah angka 18.250 hari ini dikurang dengan waktu tidur anda selama 8 jam anggap saja. Maka 18.250 hari dikali dengan 8 jam $=146.000$ jam atau sekitar 16 tahun lebih 7 bulan atau kita bulatkan menjadi 17 tahun. Jadi dalam rentang waktu anda mulai baligh di usia 15 tahun sampai usia meninggal di 65 tahun, ada waktu 17 tahun yang hanya digunakan untuk tidur saja. Angka ini belum ditambah dengan jumlah jam yang sering kita pakai pula untuk tidur siang misalnya. Subhanallah. Dalam 50 tahun waktu hidup anda pasca 
Desy Aniqotsunainy : Effective Presentation Skill pada Kegiatan Apersepsi Materi Pendidikan Agama Islam

baligh yang habis dipakai aktivitas adalah 18.250 hari $\mathrm{x}$ 12 jam (yaitu waktu di mana siang hari biasanya untuk kerja, sekolah, kuliah, berdagang, memasak dan sebagainya) maka diperoleh angka $219.000 \mathrm{Jam}$ atau $=$ 25 tahun. Belum lagi dikurangi dengan waktu anda yang biasanya digunakan untuk bersantai, istirahat sambil menonton televisi, bercanda sesama teman dan sejenisnya plus minus 4 jam, maka total dalam 50 tahun waktu yang dipakai untuk rileksasi tadi adalah 18.250 hari $\times 4$ jam=73.000 Jam atau selama 8 tahun. Alhasil, selama 50 tahun masa hidup kita pasca baligh, ada angka 17 tahun lamanya kita tidur + 25 tahun untuk beraktivitas di siang hari +8 tahun untuk sekedar rileksasi dan mencari hiburan diperolehlah angka 50 tahun. Jadi umur kita 50 tahun setelah dipotong masa baligh impas saja. Lalu jika usia 50 tahun ini tidak diisi dengan banyak hal yang positif, hal-hal yang bersifat ibadah pada Allah, maka manusia benar-benar berada dalam kerugian seperti firman Allah di dalam surat Al-Ashr. ${ }^{213}$

Atau contoh lain tentang keteladanan kekayaan dari para sahabat Rasulullah SAW:

"Fakta sejarah, adakah sahabat Nabi yang tidak kaya? Diantara empat sahabat tersekat Nabi, ternyata hanya Ali Bin Abu Thalib yang tidak kaya. Umar bin Khattab mewariskan 70.000 properti senilai triliunan rupiah (silahkan baca buku Fiqih Ekonomi Umar Karya Dr. Jaribah). Kemudian Usman bin Affan mewariskan

213 Ainul Wafa, Matematika Kehidupan dan Hikmah Di Balik Musibah, www. dakwatuna.com diakses pada tanggal 20 Maret 2017 
Desy Aniqotsunainy : Effective Presentation Skill pada Kegiatan Apersepsi Materi Pendidikan Agama Islam

property sepanjang wilayah Aris dan Khaibar senilai triliunan rupiah. 214 Perihal keberlimpahan akan menyita perhatian dan membuka mata siapa saja yang mendengar. Akan tetapi fakta sejarah tersebut dikaitkan dengan keberkahan dan menekankan bahwa Allah Yang Maha Kaya sangat menganjurkan dan mengajarkan hamba-Nya untuk Kaya. Buktinya tertulis dalam Al-Qur'an Surat An-Najm ayat 48 Allah berfirman:

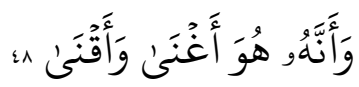

Artinya:

"Dan bahwasanya Dia yang memberikan kekayaan dan memberikan kecukupan" (QS.An-Najm: 48)

Menggunakan fakta dan data yang relevan akan membuat audiens tersentak. Apalagi jika data tersebut belum pernah mereka dengar sebelumnya dan mengungkap fakta yang dramatis.

5) Membuka Presentasi Dengan Kutipan atau Pernyataan.

Anda juga bisa membuka presentasi dengan mengutip Ayat Al-Qur'an/ Hadits/Ijtihad/ perkataan tokoh terkenal. Pembukaan seperti ini akan menarik jika kutipan yang dipilih relevan dengan topik presentasi Anda. Namun, jangan memaksakan menggunakan kutipan jika tidak relevan dengan materi presentasi Anda.

214 Ippho Santosa, Percepatan Rezeki K Dalam 40 hari Dengan Otak Kanan", Jakarta: PT Elex Media Komputindo, 2012), hlm. 18 
Desy Aniqotsunainy : Effective Presentation Skill pada Kegiatan Apersepsi Materi Pendidikan Agama Islam

Contoh:

"Bayangkan saja orang sekaya Sandiaga Uno (Wakil Gubernur DKI) berdakwah, "Kalau ingin sukses, rutinkan shalat Dhuha". Efek yang terjadi sudah mampu mempengaruhi masyarakat yang terinspirasi dengan kharismatik Sandiaga Uno. Atau guru menyampaikan hadis nabi: Sebagaimana Abu hurairah berkata: "Kekasihku (Nabi SAW) berwasiat kepada ku tiga hal dan aku pun tidak meninggalkannya. Yaitu, Tidak tidur sebelum witir, tidak meninggalkan dua rakaat shalat dhuha sebab itu adalah shalat para awwabin, serta berpuasa pada tiga hari pada setiap bulan" (HR. Bukhari). 215

Sekali lagi, Sunah Nabi, kisah sahabat-sahabat Nabi, atau perkataan tokoh terkenal dapat diambil suatu pesan bahwa berdakwah sesuai zaman dan bahasa kaumnya. Mengajak siswa bersedekah dan memfokuskan diri menjadi salah satu awwabin (orangorang yang ingat) dan lakukanlah shalat dhuha. Supaya hidup dan rezeki penuh dengan barokah.

\section{PENUTUP}

Perubahan paradigma pembelajaran tidak mengurangi kedudukan penting peranan guru. Untuk itu usaha pengembangan guru kreatif dapat dilatih dengan membuat inovasi, memberikan motivasi dan mampu membangun makna dalam penyampaian materi dalam cara mengajar (metode) atau penyampaian materi oleh guru. Kegiatan apersepsi merupakan

215 Muhammad K. Hilmy, The True Power Of Ibadah Syariat, (Yogyakarta: Sajadah press, 2008), hlm. 11 
Desy Aniqotsunainy : Effective Presentation Skill pada Kegiatan Apersepsi Materi Pendidikan Agama Islam kekuatan guru untuk menyajikan presentasi yang menarik dan bermakna. Karena siswa cenderung mengingat lebih baik apa-apa yang paling awal mereka lihat dan dengarkan. 
Desy Aniqotsunainy : Effective Presentation Skill pada Kegiatan Apersepsi Materi

Pendidikan Agama Islam

\section{DAFTAR PUSTAKA}

Ary Ginanjar Agustian. 2001. Emotional Spiritual Quotient, Jakarta: Arga Wijaya Persada.

Ainul Wafa, Matematika Kehidupan dan Hikmah Di Balik Musibah, www. dakwatuna.com diakses pada tanggal 20 Maret 2017

Departemen Agama RI. 1995. Al-Qur'an dan Terjemahnya, Surabaya: Surya Cipta Aksara.

Ippho Santosa. 2012. Percepatan Rezeki K Dalam 40 hari Dengan Otak Kanan. Jakarta: PT Elex Media Komputindo.

Nasution. 2006. Berbagai Pendekatan Dalam Proses Belajar dan Mengajar. Jakarta, Bumi Aksara.

Naim, Ngainun. 2009. Menjadi Guru Inspiratif. Yogyakarta: Pustaka Pelajar.

Muhammad K. Hilmy. 2008. The True Power Of Ibadah Syariat, Yogyakarta: Sajadah press.

Joko Susilo. 2006. Gaya Belajar Menjadikan Makin Pintar.Yogyakarta: Press.

Yusuf Mansur. 2008. The Miracle of Giving: Keajaiban Sedekah, Jakarta: Zikrul Hakim. 